\section{That certain time in history}

\author{
W.H. Brock
}

The Age of Science. By David Knight. Basil Blackwell: 1986. Pp.251. £17.50, $\$ 24.95$.

THE reappraisal of the Victorians began in the 1940 s. Much derided in the 1920 s, today even politicians are reminting a specially-selected set of their "values" for the 1980s. Notwithstanding the material and cultural gaps between 1986 and 1886 or 1836 , much of our present world can be clearly seen as derived from the Victorians - notably because of the vigorous export, through travel and emigration, of Victorian institutions and attitudes overseas, including parliamentary government, schools and universities, and the civil service, and religion and attitudes towards women and the family. Arguably, even the harmonies of contemporary popular music are those of Victorian church music. And, outside the relativistic and quantum boundaries of atomic physics and astrophysics, our vaunted twentieth-century science is essentially Victorian in origin.

In The Age of Science, David Knight, the most prolific of contemporary English historians of science (this is his eighth book), examines the scientific world-view in the nineteenth century. Although we may well believe that our present era is unprecedented in its domination by science, the reader will be persuaded by
Knight that science equally dominated nineteenth-century thought and debates on religion, education, literature and the economic viability of the nation, though in a very different manner to our own. Here was a period before disciplines became so specialized that their practitioners became alienated from one another, when scientist, clergyman, writer and artist still spoke a common cultural language, and when science was ambitious, cocksure of progress and in its hegemonic role as the Church Scientific. As Knight points out, whereas historians may (wrongly) ignore the impact of science on earlier centuries, science cannot be left out of the narrative of Victorian history or of the historians' repertoire of explanations of what happened in history.

Knight writes deftly and entertainingly. Whether examining Anglo-French scientific rivalry, the challenge of German science, Victorian criteria for science and pseudoscience, the use and significance of scientific illustrations, symbols and jargon, the symbiosis of Victorian science and religion, or the slow erosion of scientific certitude, he wears his learning lightly. The Age of Science, a summary of the specialized reading Knight has done during the past 20 years, is a tour de force. It not only succeeds in making the history of science popular, but restores its 1950 s role as a bridge between the cultures and disciplines which are the consequence of the Victorians' age of science.

W.H. Brock is Director of the Victorian Studies Centre and Reader in the History of Science at the University of Leicester, Leicester LEI 7RH, UK.

\section{Cold comforts}

\section{Beverly Halstead}

How to Deep-Freeze a Mammoth. By Björn Kurtén. Columbia University Press:1986. Pp.121. \$16.96.

A sCIENTIST's general musings in a series of light essays on his subject are the dread of reviewers; few ever rise to the riveting heights of a Stephen Jay Gould. Björn Kurtén's slim volume, however, is well above the average. Kurtén specializes in the study of mammals of the Ice Age, and he has written fictional accounts of the life and times of the period.

Most of the essays deal with aspects of the Pleistocene, but also cover such topics as the third early bird Archaeopteryx, the early history of continental drift and the great Messinian salinity crisis when the Mediterranean dried out. This last event came to light when salt deposits $1.5-2 \mathrm{~km}$ in depth were discovered during the deepsea drilling prograamme; after the drought came the flood, as the Atlantic poured in through the Straits of Gibraltar - the largest waterfall in Earth history.

It is, however, in writing about the Pleistocene that Kurtén has the surest touch - he does in fact explain how to deep-freeze a mammoth. It has happened but rarely. Normally the outer layers freeze but the deeper parts putrefy and all that remain are bones and bacteria. However, on a southern-facing slope in winter, it is possible for an entire animal to be freeze-dried, and Kurtén describes the discovery of a 30,000-year-old bison from Alaska which made a palatable stew.

There is, too, an essay on Piltdown Man; here, being a Finn Kurtén misses some of the subtlety of English humour. He refers to the "elephant club" from Piltdown that had been carved with a steel knife, but this unique artefact was seen by all, even the duped Sir Arthur SmithWoodward in his book The First Englishman, as akin to a cricket bat. What else would the first Englishman require? The first European in the form of the nownotorious Petralona skull from Greece is featured, but in this case the discussion verges on the technical as Kurtén has been personally involved. In general, though, he has a light touch. Most of the essays are very readable, and the first and last of them are outstanding.

In the first, entitled "The Two Cultures", Kurtén contrasts the fundamental difference between physics and chemistry on the one hand, and biology on the other, expressing with great clarity the attitudes of many practitioners of the "woolly" sciences:

But the world of physics is no more than a corner of the world of science. A man is greater than a star. A bacterium is greater than a star. A star cannot become very much else than a star - but bacteria have evolved into men ... Biology is the study of individuals, all of them unique, in inexpressible multiplicity and richness. And so the world of biology is something very different from the world of physics and calls for a different approach and different concepts.

The last essay is on cave art. It may be wondered if there could possibly be anything more to say that has not already been said many times before, but one surprising fact is that it appears that the Ice Age was a Golden Age: there was an abundance of food and the lifespan of human beings was not paralleled until virtually the present day. Furthermore, when cave art is examined from the standpoint of a zoologist an unusual perspective emerges: a male reindeer on heat or seals swimming upside down, there is a remarkable precision of observation. Kurtén suggests that many of the paintings may have been for children, in fact for their education. Interestingly, children's footprints are common on the floors of these caves. It would be important for them to recognize the animal's state and hence predict its behaviour.

When it comes to the portrayal of the human form, Kurtén points out that here too there is great accuracy of observation. He notes that many examples of cave art portray sexually inviting attitudes and are not dissimilar to photographs in pornographic magazines of the present day. The vulva is seen frontally, inverted and also from the back, open for penetration. Kurtén sees "unabashed sensual joy and tenderness" in all this. One has the distinct impression that palaeolithic man had a very great interest in and knowledge of sex, and he seems to have portrayed many species including his own in states of sexual arousal. Kurtén must surely be right; it must have been a Golden Age.

Beverly Halstead is a Reader in the Departments of Geology and Zoology, University of Reading, Whiteknights, Reading RG62AH, UK.

- Recently published by the British Museum (Natural History) in the UK, and Facts on File in the United States, is Mammal Evolution: An Illustrated Guide, with text by R.J.G. Savage and illustrations by M.R. Long. The book will be reviewed in a future issue of Nature. 